\title{
EKSISTENSI PERADILAN ADAT DALAM PERATURAN PERUNDANGAN-UNDANGAN DI INDONESIA
}

(Melacak Berlakunya Kembali Peradilan Adat Di Indonesia Dan Relevansinya Bagi Upaya Pembangunan Hukum Nasional)

\section{FATHOR RAHMAN}

\author{
Advokat dan konsultan hukum pada LKH PM Kota Malang
}

fatur_elfa@yahoo.com

\begin{abstract}
Customary courts are judicial institutions that live in the community based on local customs. Diversity of customary courts is identified with the characteristics of each region. The existence of customary courts has lived for a long time and is currently strengthened by various kinds of policy regulations. Post-independence Indonesia, customary justice continues to live side by side with other courts. It is interesting to study related to the relevance of the existence of customary courts in Indonesia associated with national development. The method used in examining the problem is a normative juridical method with a library approach.

Keywords : existence, cutomary court, legislation
\end{abstract}

\begin{abstract}
Abstrak, Peradilan adat merupakan institusi peradilan yang hidup dalam masyarakat yang dilandasi adat istiadat setempat. Keanekaragaman peradilan adat diidentikkan dengan karakteristik masing-masing wilayah. Keberadaan peradilan adat telah hidup sejak lama dan saat ini dikuatkan dengan berbagai macam regulasi kebijakan. Pasca Indonesia merdeka, peradilan adat tetap hidup berdampingan dengan peradilan lainnya. Menarik untuk dikaji terkait dengan relevansi keberadaan peradilan adat di Indonesia dikaitkan dengan pembangunan nasional. Metode yang digunakan dalam menelaah permasalahan yaitu metode yuridis normatif dengan pendekatan kepustakaan (library research).

Kata Kunci : eksistensi, peradilan adat, peraturan perundang-undangan
\end{abstract}

\section{Pendahuluan}

Setelah Indonesia merdeka, upaya untuk membangun hukum nasional yang berdasarkan atas keperibadian bangsa Indonesia terus dilakukan. Di awal kemerdekaannya, Indonesia yang belum stabil masih belum mampu membuat peraturan perundang-undanganyang lengkap untuk mengatur segala aspek dalam kehidupan berbangsa dan bernegara. Maka agar tidak terjadi kekosongan hukum yang dapat berakibat kekacauan, hukum yang berlaku pada masa pemerintahan kolonial Belanda masih tetap diberlakukan dengan mengacu pada Pasal II Aturan Peralihan UndangUndang Dasar Negara Republik Indonesia Tahun 1945, Pasal 192 Konstitusi Republik Indonesia Serikat, serta Pasal 142 Undang-Undang Dasar Sementara $1950^{1}$. Dengan disahkannya Undang-Undang Dasar Negara Republik Indonesia Tahun 1945maka

\footnotetext{
${ }^{1}$ Abdul Jamali, Pengantar Hukum Indonesia, (Jakarta: CV. Raja Wali, tt.), hlm. 65-70.
} 
bangsa Indonesia mempunyai dasar-dasar daripada tertib hukum baru, hukum yang mencerminkan kepribadian bangsa Indonesia untuk mengatur tata tertib hidup bangsa Indonesia dan masyarakat Indonesia baru.

Dari waktu ke waktu pembanguan dan perkembangan hukum di Indonesia terus mengalami dinamika sesuai dengan kebijakan dan politik hukum yang diterapkan oleh Pemerintah, dan terus menyesuaikan dengan tuntutan beberapa pihak untuk menciptakan hukum yang lahir dari nila-nilai keperibadian bangsa Indonesia. Berbagai macam persoalan yang dihadapi Negara Indonesia menuntut hukum untuk terus bergerak maju sebagai pengendali sosial dan menjadi garda terdepan dalam menciptakan masyarakat yang tertib, maju, dan sejahtera.

Perkembangan hukum itu ditandai dengan lahirnya berbagai macam produk hukum baru, dan ini merupakan tuntutan darisebagian besar masyarakat, untuk membangun hukum nasioanal dengan menggali nilai-nilai yang hidup dalam masyarakat tersebut. ${ }^{2}$ Sejak bergulirnya era reformasi, gaung tuntutan masyarakat untuk membentuk hukum yang bersumber dari nlai-nilai yang hidup dalam masayarakat terus bergema,terutama mengenai aturan yang bersifat konstusional dan perundang-undangan agar mengakomodir hukum adat sebagai hukum tidak tertulis yang tercermin dari nilai keadilan dan norma yang hidup dan tumbuh di masyarakat (the living law), atau setidaknya harusdijadikan sumber hukum yang harus digali, diperhatikan dan dihormati terutama dalam praktik penegakan hukum ${ }^{3}$,termasuk dalam hal ini peraturan perundangundangan yang berkaitan dengan sistem peradilan di Indonesia demi tegaknya hukum dan keadilan.

Dalam pasal Undang-Undang Dasar Negara Republik Indonesia Tahun1945, telah mengatur sistem penyelenggaraan peradilan Indonesia yang berbunyi sebagai berikut : “

(1). Kekuasaan Kehakiman merupakan kekuasaan yang merdeka untuk menyelenggarakan peradilan guna menegakkan hukum dan keadilan. (2). Kekuasaan kehakiman dilakukan oleh sebuah Mahkamah Agung dan badan peradilan yang berada di bawahnya dalam lingkungan peradilan umum, lingkungan peradilan agama, lingkungan peradilan militer, lingkungan peradilan tata usaha negara, dan oleh sebuah Mahkamah Konstitusi. (3). Badan-badan lain yang fungsinya berkaitan dengan kekuasaan kehakiman diatur dalam undang-undang ${ }^{4}$.

Berdasarkan ketentuan pasal 24 ayat (3) Undang-Undang Dasar Negara Republik Indonesia Tahun 1945, membuka peluang adanya peradilan-peradilan lain yang fungsinya berkaitan dengan kekuasaan kehakiman, selain Mahkamah Agung dan badan-badan dibawahnya yang meliputi, Peradilan Umum, Peradilan Agama, Peradilan Militer, Peradilan Tata Usaha Negara, dan sebuah Mahkamah Konstitusi seperti yang disebutkan dalam pasal 24 ayat (2) Undang-Undang Dasar Negara Republik Indonesia Tahun 1945,

\footnotetext{
${ }^{2}$ Visi dan Arah Pembangunan Jangka Panjang (PJP) Tahun 2005 - 2025, Kantor Menteri Negara Perencanaan Pembangunan Nasional/ Badan Perencanaan Pembangunan Nasional, hlm. 4.

${ }^{3}$ Lihat Pasal 5 jo. Pasal 10 ayat (2) Undang-Undang Nomor 48 Tahun 2009 tentang Kekuasaan Kehakiman (Lembaran Negara Republik Indonesia Nomor 157 Tahun 2009, Tambahan Lembaran Negara Republik Indonesia Nomor 5076).

${ }^{4}$ Pasal 24 Undang-Undang dasar Negara Republik Indonesia 1945 hasil amandemen.
} 
maka peradilan-peradilan lain yang berbasis pada peradilan adat menjadi terbuka, sepanjang diatur dalam Undang-Undang ${ }^{5}$.

Ha ini sejalan dengan pokok-pokok pembangunan hukum yang tertuangdalam visi dan arah Rencana Pembangunan Jangka Panjang Nasional Tahun 2005-2025, yaitu :

“... Salah satu tugas yang sampai dengan saat ini belum dituntaskan adalah membentuk Sistem Hukum Nasional Indonesia yang mencerminkan cita-cita, jiwa, semangat serta nilai-nilai sosial yang hidup di Indonesia.Upaya yang dilakukan antara lain (1) pembaruan peraturan perundang-undangan; (2) pemberdayaan institusi/lembaga hukum yang ada; (3) peningkatan integritas dan moral aparat penegak hukum dan aparatur hukum lainnya; disertai dengan (4) peningkatan sarana dan prasarana hukum yang memadai. Pembaruan peraturan perundang-undangan terus-menerus dilakukan baik dengan mengganti peraturan perundangundangan kolonial maupun berbagai peraturan perundangundangan nasional yang tidak sesuai dengan nilai-nilai sosial dan kebutuhan Bangsa Indonesia...."

Berdasarkan visi dan arah dari RPJPN tahun 2005-2025 tersebut, nampak dengan jelas, bahwa upaya pembangunan hukum, harus sejalan dengan cita-cita, jiwa, semangat serta nilai-nilai sosial yang hidup di Indonesia, yang tidak hanya dimakanai dari persepektif substansi hukum, melainkan juga dari perspektif institusi, yang juga harus menggali nlai-nilai dan krakter bangsa inidonesia. Seperti instituisi peradilan adat, yang akhir-akhir ini menjadi topik yang ramai dibicarakan di berbagai kalangan baik dalam disikusi ilmiah di tingkat lokal maupun nasional dalam beberapa tahun terakhir. Munculnya isu peradilan adat tersebut tidak lain adalah karena selama bertahun-tahun keberadaan peradilan adat telah berangsur-angsur dihapuskan melalui Undang-Undang Darurat Nomor 1 Tahun 1951 Tentang Tindakan-Tindakan Sementara Untuk Menyelenggarakan Kesatuan Susunan, Kekuasaan Dan Acara Pengadilan-Pengadilan Sipil.Pada Pasal 1 ayat (2) huruf b, telah menyatakan bahwa:

"Pada saat yang berangsur-angsur akan ditentukan oleh Menteri Kehakiman dihapuskan: (1) Segala Pengadilan Swapraja (Zelfbestuurs-rechtspraak) dalam Negara Sumatera Timur dahulu, Karesidenan kalimantan Barat dahulu dan Negara Indonesia Timur dahulu, kecuali peradilan Agama jika peradilan itu menurut hukum yang hidup merupakan satu bagian tersendiri dari peradilan Swapraja; (2). Segala Pengadilan Adat (Inheemse rechtspraak in rechtstreeksbestuurd gebied),kecuali peradilan Agama jika peradilan itu menurut hukum yang hidup merupakan satu bagian tersendiri dari peradilan Adat"

Berdasarkan Undang-Undang Darurat Nomor 1 tahun 1951 Tentang TindakanTindakan Sementara Untuk Menyelenggarakan Kesatuan Susunan, Kekuasaan Dan Acara Pengadilan-Pengadilan Sipil, pada Pasal 1 ayat (2) huruf b, tersebut, memang peradilan adat atau yang dipersamakan dengan peradilan adat tersebut telah dihapuskan, namun dalam perjalanan selanjutanya, terutama pasca reformasi pada tahun 1998 keberadaan

${ }^{5}$ Ketut Sudantra, Pengakuan Peradilan Adat dalam Politik Hukum Kekuasaan Kehakiman, (Bali: Udayana University Press, 2004), hlm. 7, dalam Laodi Munawir, (Malang, Disertasi Program Doktor Ilmu Hukum Universitas Brawijaya: 2018).

${ }^{6}$ Visi dan Arah Pembangunan Jangka Panjang (PJP) Tahun 2005 - 2025, Op. Cit., hlm. 4.

${ }^{7}$ Lihat dalam Pasal 1 Undang-Undang Darurat Nomor 1 Tahun 1951 Tentang TindakanTindakan Sementara Untuk Menyelenggarakan Kesatuan Susunan, Kekuasaan Dan Acara Pengadilan-Pengadilan Sipil. 
peradilan adat secara yuridis kemabli dihidupkan dan pengaturannya terdapat dalam beberapa peraturan perundang-undangan.Hal ini disebabkan, di dalam masyarakat adat, sering terjadi ketegangan-ketegangan sosial, olehkarena terjadi pelanggaran adat oleh seseorang atau sekelompok warga masyarakatdalam suatu lingkungan adat. Peristiwa ketegangan sosial tersebut akan pulih kembalijika terjadi reaksi masyarakat yang berupa sanksi adat dan telah dilaksanakan atau dipatuhi oleh si pelanggar yang menimbulkan ketegangan tersebut.

Pelanggaran adatadalah suatu perbuatan sepihak dari seseorang atau sekumpulan perseorangan,mengancam atau menyinggung atau mengganggu keseimbangan dari kehidupanpersekutuan baik bersifat materiil maupun immaterial, terhadap seseorang ataumasyarakat berupa kesatuan adat. Tindakan yang demikian akan mengakibatkan suatureaksi adat ${ }^{8}$. Terhadap beberapa kasus yang bernuansa perselisihan adat, dan sebenarnya bisa diselesaikan melalui otoritas adat, speperti Kepala Adat, Kepala Desa, dan lain sebainya, sejak berlakunayaUndang-Undang Darurat Nomor 1 tahun 1951 Tentang Tindakan-Tindakan Sementara Untuk Menyelenggarakan Kesatuan Susunan, Kekuasaan Dan Acara Pengadilan-Pengadilan Sipil sudah ditinggalkan, dan lebih memilih dibawa ke muka Peradilan Negara (umum), dan kemudian putusannya tidak mencerminkan nila-nilai keadilan, yang berlandaskan kearifan lokal, tidak mencerminkan keadilan dan kemanfaatan yang menjunjung tinggi nilai-nilai adat, namun sebaliknya, putusan tersebut justru melukai keadilan, terutama apabila dikaitkan dengan eksistensi nilai-nilai kearifan lokal. Hal ini yang kemudian, menimbulkan dorongan untuk kembali menghidupkan peradilan adat, sebagai alternatif penyelesaian sengketa bagi masyarakat untuk menyelesaikan permasalahan hukum, di luar Pengadilan Negara (umum) yang sering menghasilkan keputuan yang tidak mencerminkan nilai-nilai adat dan kearifan lokal.

Peradilan adat merupakan suatu lembaga peradilan perdamaianantara para warga masyarakat hukum adat di lingkungan masyarakat hukumadat yang ada ${ }^{9}$.Peradilan adat merupakan terminologi normatif yang disebutkan dalam berbagai peraturan perundangundangan, terutama dalam peraturan perundang-undangan yang lahirnya setelah reformasi.Namun terminologi legal formal tersebut dikenal dengan istilah yang berbeda oleh masyarakat. Beberapa masyarakat kesatuan hukum adat menyebut lembaga pengadilan adat dengan istilah yang beragam, misalnya "sidingadat", "para-para adat", "pokara adat", atau "rapatadat", serta berbagai istilah menurut kekhasan bahasa lokal setempat.Dan ini secara perlahan kemudian mendorong lahirnya kembali peradilan adat yang eksistensinya diakui secara yuridis dalam sistem peradilan di Indonesia ${ }^{10}$.

Berangkat dari urain tersebut, menjadi menarik untuk dibahas secara mendalam, dan penulis tertarik untuk melacak eksistensi dan diberlakukannya kembali sisitem peradilan adat, dan menjadi bagian dari sistem peradilan yang menyeluruh dalam sistem

${ }^{8}$ Bushar Muhammad, Pokok-Pokok Hukum Adat, (Jakarta: PT. Pradnya Paramita, 1983), hlm. 67.

${ }^{9}$ Sudikno Mertokusumo, Mengenal Hukum, (Yogyakarta: Liberti, 1999), hlm.3.

10 Ewa Wojkoswka, "How Informal Justice System Can Contribute", Paper, United Nations Development Program Oslo Governance Centre, Oslo, Desember 2006, hlm. 11. Dalam Tody Sasmitha Jiwa Utamadan Sandra Dini Febri Aristya, Kajian Tentang Relevansi Peradilan Adat Terhadap Sistem Peradilan Perdata Indonesia, Makalah : Bagian Hukum Adat dan Bagian Hukum Acara Fakultas Hukum Universitas Gadjah Mada, Yogyakarta.. 
peradilan Indonesia, kaitannya dengan upaya pembangunan hukum nasional yang terus berkesinambungan, dengan judul : EKSISTENSI PERADILAN ADAT DALAM PERATURAN PERUNDANGAN-UNDANGAN DI INDONESIA (Melacak Eksistensi Peradilan Adat Di Indonesia Dan Relevansinya Bagi Upaya Pembangunan Hukum Nasional)

Berdasarkan uraian yang telah dipaparkan di atas, maka dapat ditentukan beberapa rumusan masalah yaitu: Bagaimana Eksistensi Peradilan Adat Dalam Peraturan Perundangan-Undangan di Indonesia?. Dan, Apa Relevansi Eksistensi Peradilan adat di Indonesia dengan Pembangunan Hukum Nasional ?

\section{Pembahasan}

\section{A. Eksistensi Peradilan Adat Dalam Peraturan Perundangan-Undangan di Indonesia}

Dalam Kamus Besar Bahasa Indonesia disebutkan bahwa Eksistensi berarti adanya atau keberadaan ${ }^{11}$.Pengertian Peradilan menurut Kamus Besar Bahasa Indonesia adalah segala sesuatu mengenai perkara pengadilan ${ }^{12}$.Menurut kamus hukum peradilan adalah segala sesuatu yang berhubungan dengan tugas Negara menegakan hukum dan peradilan ${ }^{13}$.Jadi peradilan adat adalah peradilan yang diadakan untuk menyelesaikan perkara-perkara yang timbul dalam suatau masyarakat adat.Secara yuridis pengertian peradilan adat bisa ditemui dalam beberapa peraturan perundang-undangan, yang menyebutkan bahwa peradilan adat adalah peradilan perdamaian di lingkungan masyarakat hukum adat, yang mempunyai kewenangan memeriksa dan mengadili sengketa perdata adat dan perkara pidana di antara para warga masyarakat hukum adat yang bersangkutan ${ }^{14}$.

Melacak eksistensi peradilan adat di Indonesia tidak bisa lepas dari sejarah berlakunya sistem peradilan di Indonesia, mulai sejak zaman pra kemerdekaan sampai sekarang, dimana Indonesia telah menganut sistem peradilan yang modern.Sebelum Indonesia merdeka, kolonialisasi Belanda terhadap kerajaan-kerajaan di Nusantara telah mengubah sistem peradilan di nusantara mengikut kepada undang-undang formal yang dibawa Belanda.

Dalam urusan peradilan, bisa dilacak sejak Daendels dengan menggunakan Pasal 86 "charter" 1804 sebagai dasar bagi peradilan untuk golongan bumi putera, yakni "susunan peradilan untuk bangsa bumi putera akan tetap tinggal menurut hukum serta adat mereka ${ }^{15 \%}$. Atas dasar itu, menurut Soepomo,Pemerintah Hindia Belanda akan

\footnotetext{
${ }^{11}$ Tim Penyusun Pusat Pengembangan Bahasa, Kamus Besar Bahasa Indonesia, (Jakarta : Balai Pustaka, 1990), hlm.368.

${ }^{12}$ Ibid.

13 Subekti, dan R.Tjitrosoedibio, Kamus Hukum, (Jakarta : PT Pradnya Paramita, 2003), hlm.68.

${ }^{14}$ Salah satunya terdapat dalam Undang-Undang Nomor 21 Tahun 2001 tentang Otonomi Khusus Papua pasal 51ayat (1).

${ }^{15}$ Pasal 86 "charter" 1804, dalam Teuku Muttaqin Mansur dan Faridah Jalil, Aspek Hukum Peradilan Adat Di Indonesia Periode 1602 - 2009, Jurnal : Kanun Jurnal Ilmu Hukum No. 59, Th. XV (April, 2013), hlm. 65.
} 
menjaga dengan alat-alat yang pantas supaya dalam daerah yang dikuasai oleh pemerintah Hindia Belanda sedapatnya terhapus semua perbuatan sewenang-wenang yang masuk secara diam-diam, yang berlawanan dengan hukum serta adat anak negeri ${ }^{16}$.

Pada tahun 1814, baru dikenal secara jelas, asal muasal hukum adat di Indonesia, yakni melalui peraturan Raffles tahun 1814. Peraturan tersebut menyebutkan bahwa "para residen (kepala daerah setempat) yang mengetahui peradilan wajib melakukan undangundang (ketentuan) dan kesusilaan asli yang telah ada sebelumnya, asal hukum adat tidak bertentangan dengan "the universal and acnowledged principles of natural justice". Dan dalam Pasal 11 AB,yang kemudian dirubah menjadi Pasal 75 RR.Bagi masyarakat bumi putera, peradilan yang diakui ialah sesuai dengan Pasal 11 AB (Alglemene Bepalingen, ketentuan hukum perundang-Undangan yang berlaku di Indonesia) yang berbunyi :“... maka hukum yang berlaku dan dilakukan oleh hakim penduduk asli (inlandse rechter), bagi mereka itu adalah undang-uundang agama mereka, lembaga-lembaga dan kebiasaan rakyat, asal saja asas-asas keadilan yg diakui umum"17.

Pada tahun 1925, RR di ganti namanya menjadi Indieshe Staatregeling (IS), kodifikasi hukum pokok ketatanegaraan, di mana Pasal 75 RR tersebut menjadi Pasal 131 IS. Namun Pasal 131 IS baru berlaku mulai tanggal 1 Januari 1926 dengan redaksi sebagai berikut :

"dalam mengadakan ordonansi-ordonansi yang memuat hukum sivil dan dagang pembuat ordonansi akan meperhatikan bahwa : Bagi golongan orang bumi putera (asli), golongan timur asing dan bagian-bagiannya, berlaku peraturan hukum yang didasarkan atas nama agama-agama dan kebiasaan mereka; tetapi terhadap peraturan-peraturan tersebut dapat dikecualikan apabila kepentingan umum atau keperluan sosial mereka memerlukan maka dapat ditetapkan bagi mereka hukum eropa - jika perlu dengan perubahan ataupun hukum yg berlaku bagi mereka dan golongan orang Eropa bersamasama.

Jadi, baik dalam $A B$, RR maupun dalam IS, dapat dipahami bahwa ada peradilan tersendiri bagi penduduk bumi putera (penduduk asli) dalam menyelesaikan kasus yang terjadi ditengah-tengah mereka yakni dijalankan oleh hakim bumi putera.

Setelah kemerdekaan, ada beberapa dasar hukum yang dijadikan sandaran bagi berlakunya peradilan adat.Konstitusi Republik Indonesia Serikat (RIS) yang terbentuk pada tahun 1949 misalnya mengakui bahwa seluruh putusan peradilan di Indonesia harus memuat hukum adat.Pasal 146 (1) RIS menyebutkan "segala keputusan kehakiman harus berisi alasan-alasannya dan dalam perkara hukuman harus menyebut aturan UU dan aturan hukum adat yang dijadikan dasar hukuman itu". Kemudian ketika beralih kepda UUDS, Pasal yang sama juga muncul kembali dalam Undang-Undang Sementara (UUDS) pada tahun 1950.Tahun 1951, diterbitkan Undang-Undang Darurat Nomor 1 tahun 1951 tentang tindakan-tindakan sementara untuk menyelenggarakan kekuasaan, susunan kekuasaan dan acara peradilan. Maka peradilan bumi putera yang juga disebut peradilan adat, peradilan swapraja berdasarkan ketetuan masa kompeni berangsur-angsur dihapuskan.Sedangkan peradilan desa yang di atur dalam Pasal 3 a RO (reglement op de

${ }^{16}$ R Soepomo, Sejarah Politik Hukum Adat, 1, (Jakarta: Pradnya Paramita, 1982), hlm. 9. Dalam Teuku Muttaqin Mansur dan Faridah Jalil, hlm. 67.

${ }^{17}$ Teuku Muttaqin Mansur dan Faridah Jalil, Op. Cit. hlm. 69. 
rechterlijke organisatie, peraturan susunan peradilan dan pengurusan justisi) sedikitpun tidak dikurangi kewenangannya.

Dari situ mulailah terlihat adanya pelemahan kekuasaan yang dimiliki peradilan adat.Apabila sebelumnya dapat menjatuhkan juga sanksi keras dalam perkara-perkara pidana, namun akibat berlakunya Undang-Undang Darurat Nomor 1 tahun 1951, kewenangan tersebut diperlemah.Hakim adat hanya digolongkan sebagai hakim perdamaian dengan perkara-perkara pelanggaran kecil-kecil saja. Peradilan adat pada masa lalu dengan peradilan bumi putera memisahkan hukum materil dan formilnya, akan tetapi setelah ada Undang-Undang Darurat Nomor 1 tahun 1951, ketentuan materil (hukum adat) dan formil (peradilan) bagi telah diunifikasikan menjadi satu.Dalam perjalanan selanjutnya, munculnya Undang-Undang Nomor 5 Tahun 1979 Tentang Pemerintahan Desa.UU inipun telah menjadi masalah bukan saja telah meniadakan eksistensi masyarakat hukum adat, tetapi juga telah meniadakan hak masyarakat hukum adat tersebut terhadap tanah ulayatnya. ${ }^{18}$

Setelah Indonesia memasuki era reformasi pada tahun 1998 yang ditandai dengan jatuhnya pemerintahan presiden Soeharto, maka konstitusi Negara juga telah mengalami beberapa kali perubahan. Pasal 18B Undang-Undang Dasar Negara Republik Indonesia Tahun 1945 yang merupakan perubahan Undang-Undang Dasar sebelumnya berbunyi "negara mengakui dan menghormati kesatuan-kesatuan masyarakat hukum adat beserta hak-hak tradisionalnya sepanjang masih hidup dan sesuai dengan perkembangan masyarakat dan prinsip Negara Kesatuan Republik Indonesia yang di atur dalam UndangUndang”. Selanjutnya Undang-Undang 48 tahun 2009, dalam beberapa pasalnya mulai mengakui secara tersirat mengenai keberadaan peradilan adat di Indonesia tetapi tidak menyatakan dengan tegas. Hal ini dapat dilihat dalam Pasal 10 yang berbunyi :Ayat (1) Pengadilan dilarang menolak untuk memeriksa, mengadili, dan memutus suatu perkara yang diajukan dengan dalih bahwa hukum tidak ada atau kurang jelas, melainkan wajib untuk memeriksa dan mengadilinya. Ayat (2) Ketentuan sebagaimana dimaksud pada ayat (1) tidak menutup usaha penyelesaian perkara perdata secara perdamaian.Ketentuan Pasal 10 Undang-Undang Nomor 48 tahun 2009 ini sebelumnya termuat dalam penjelasan Pasal 3 (1) dan ketentuan Pasal 16 (2) Undang-Undang Nomor 14 tahun 1970 tentang Pokok-pokok Kekuasaan Kehakiman sebagaimana telah diubah dengan UndangUndang Nomor 4 tahun 2004 tentang Kekuasaan Kehakiman. Penjelasan Pasal 3 (1) menyebutkan bahwa (semua peradilan di seluruh wilayah negara Republik Indonesia adalah peradilan negara dan ditetapkan dengan Undang-Undang) tidak menutup kemungkinan penyelesaian perkara dilakukan di luar peradilan negara melalui perdamaian atau arbitrase".Sementara bunyi Pasal 16 (2) "ketentuan sebagaimana dimaksud dalam Pasal (1) (Peradilan tidak boleh menolak untuk memeriksa, mengadili, dan memutus suatu perkara yang diajukan dengan dalih bahwa hukum tidak ada atau kurang jelas, melainkan wajib untuk memeriksa dan mengadilinya) tidak menutup kemungkinan untuk menyelesaikan perkara secara perdamaian”.

Maka apabila ditinjau dari persepektif yuridis, eksisitensi peradilan adat, pasaca digulirkannya era eformasi nampak semakin jelas dan terang disebut dalam beberapa

\footnotetext{
${ }^{18}$ Teuku Muttaqin Mansur dan Faridah Jalil, Op. Cit. hlm. 74.
} 
peraturan perundang-undangan, setidaknya dapat dilacak dalam beberapa peraturan perundang-undangan seperti berikut:

\section{Melacak Berlakunya Peradilan Adat Dalam Konstitusi}

Berangkat dari prinsip bahwa Indonesiaadalah Negara hukum, maka salah satu prinsip penting Negara hukum adalah jaminan penyelenggaraan kekuasaan kehakiman yang merdeka, bebas dari pengaruh kekuasaan lainnya untuk menyelenggarakan peradilan guna menegakan hukum dan keadilan. Maka dari itulah dalam pasal 24 UUD NRI 1945, telah mengatur sistem penyelenggaraan peradilan Indonesia yang berbunyi sebagai berikut : “

(1). Kekuasaan Kehakiman merupakan kekuasaan yang merdeka untuk menyelenggarakan peradilan guna menegakkan hukum dan keadilan. (2). Kekuasaan kehakiman dilakukan oleh sebuah Mahkamah Agung dan badan peradilan yang berada di bawahnya dalam lingkungan peradilan umum, lingkungan peradilan agama, lingkungan peradilan militer, lingkungan peradilan tata usaha negara, dan oleh sebuah Mahkamah Konstitusi. (3). Badan-badan lain yang fungsinya berkaitan dengan kekuasaan kehakiman diatur dalam undang-undang ${ }^{19}$.

Pasal tersebut mempertegas berkaitan dengan eksistensi peradilan adat, dan merupakan titik balik dari proses peradilan adat yang sejak zaman penjajahan Belanda diakui dan dianggap penting ntuk dipertahanakan, sebagai upaya pengakuan hukum yang berlandaskan nilai-nilai yang bersumber dari budaya asli masyarakat adat di Indonesia. Pasal 24 ayat (3) UUD NRI Tahun 1945, secara tegas membuka peluang adanya peradilan-peradilan lain yang fungsinya berkaitan dengan kekuasaan kehakiman, selain Mahkamah Agung dan badan-badan dibawahnya yang meiputi, Peradilan Umum, Peradilan Agama, Peradilan Militer, Peradilan Tata Usaha Negara, dan sebuah Mahkamah Konstitusi seperti yang disebutkan dalam pasal 24 ayat (2) UUD NRI Tahun 1945, maka peradilan-peradilan lain yang berbasis pada peradilan adat menjadi terbuka, sepanjang diatur dalam Undang-Undang.

Selain pasal 24 ayat (3) ) UUD NRI Tahun 1945, dalam Pasal 18B ayat (2) dikatakanUndang-Undang Dasar 1945 disebutkan bahwa: "Negara juga mengakui dan menghormati kesatuan-kesatuan masyarakat hukum adat beserta hak-hak tradisionalnya sepanjang masih hidup dan sesuai dengan perkembangan masyarakat dan prinsip Negara Kesatuan Republik Indonesia, yang diatur dalam UndangUndang"20.Selanjutnya Pasal 28I ayat (3) menyebutkan:"Identitas budaya dan hak masyarakat tradisional dihormati selaras denganperkembangan zaman dan peradaban".

Berdasarkan beberapa ketentuan dalam Undang-Undang Dasar Negara Republik Indonesia Tahun 1945 (Selanjutnya disingkat UUD RI Tahun 1945) sebagaimana yang tersebut di atas, maka berarti dapat dipahami dalam konteks sebagai berikut : Pertama, negara mengakui dan mengakomodir serta memberikan peluang untuk diberlakukannya kembali sistem peradilan lain di luar yang disebutkan

\footnotetext{
${ }^{19}$ Pasal 24 Undang-Undang dasar Negara Republik Indonesia 1945 hasil amandemin

${ }^{20}$ Undang-Undang Dasar Negara Republik Indonesia Tahun 1945, Lembaran Negara RepublikIndonesia Pasal 18B, Pustaka Mandiri, Surakarta, hlm.69.
} 
dalam ketentuan tersebut, yang dalam hal ini bisa dimakanai peradilan lain tersebut termasuk didalamnya adalah keberaadaan sistem peradilan adat. Kedua, Negara mengakui dan menghormati eksistensi kesatuan-kesatuan masyarakat hukum adat beserta hak-hak tradisionalnya; ketiga negara menghormati identitas budaya dan hak masyarakat tradisional sebagai bagian dari hak asasi manusia yang harus mendapat perlindungan, termasuk dalam hal ini pengakuan peradilan adat, yag nerupakan bagian dari identitas budaya, yang dalam beberapa dekakde terakhir ini, dinegasikan sejak dihapuskannya peradilan-peradilan non Negara dalamUndang-Undang Darurat Nomor 1 tahun 1951 Tentang Tindakan-Tindakan Sementara Untuk Menyelenggarakan Kesatuan Susunan, Kekuasaan Dan Acara Pengadilan-Pengadilan Sipil.

\section{Melacak Berlakunya Hukum Adat Dalam Undang-Undang :}

Selain Peradilan adat yang secara kontekstual diakui dalam Konstitusi Negara Indonesia, maka untuk melacak berlakunya kembali peradilan adat dalam sistem peradilan di Indonesia, dapat dilihat dai beberapa ketentuan Undang-Undang sebagaimana berikut :

\section{a. Tektualitas dan Kontekstulitas Peradilan Adat dalam Undng-Undang \\ Desa. \\ Undang-Undang Nomor 6 Tahun 2014 tentang Desa,Pasal 103 mengatur} tentang kewenangan Desa Adat berdasarkan hak asal usul yang meliputi:Menegaskan Kewenangan berdasarkan hak asal usul adalah hak yang merupakanwarisan yang masih hidup dan prakarsa Desa atau prakarsa masyarakat Desa. Kewenangan tersebut meliputi hal-hal sebagai berikut :

a. Pengaturan dan pelaksanaan pemerintahan berdasarkan susunan asli;

b. Pengaturan dan pengurusan ulayat atau wilayah adat;

c. Pelestarian nilai sosial budaya Desa Adat;

d. Penyelesaian sengketa adat berdasarkan hukum adat yang berlaku di Desa Adat dalam wilayah yang selaras dengan prinsip hak asasi manusia dengan mengutamakan penyelesaian secara musyawarah;

e. Penyelenggaraan sidang perdamaian peradilan Desa Adat sesuai denganketentuan peraturan perundang-undangan;

f. Pemeliharaan ketenteraman dan ketertiban masyarakat Desa Adatberdasarkan hukum adat yang berlaku di Desa Adat; dan

g. Pengembangan kehidupan hukum adat sesuai dengan kondisi sosial budaya masyarakat Desa Adat.

Berdasarkan ketentuan tersebut, terutama dalam poin e, secara tekstual jelas disebutkan soal "peradilan adat"yang hal ini dapat diapahami, bahwa peradilan adat, telah dihidupkan kembali, untuk menyelesaian sengketa adat berdasarkan hukum adat yang berlaku di Desa Adat dalam wilayah yang selaras dengan prinsip hak asasi manusia dengan mengutamakan penyelesaian secara musyawarah.

Selanjutnya dalam pasal 26 ayat (4) huruf k, Undang-Undnag No. 6 Tahun 2016 tentang Desa tersebut, disebutkan dan mempertegas kedudukan Kepala Desa, yang berkewajiban menyelesaikan perselisihan di masarakat Desa. Walupun tidak dijelaskan secara rigit soal bentuk perselidihan apa yang wajib diseleaikan oleh 
Kepla Desa, namun secara kontekstual dapat dimaknai bahwa Kepala Desa memiliki tugas dan wewenanguntuk menciptakan masyarakat yang aman dan tentram diantara warga desanya, dengan menyelesaikan berbagai macam konflik atau perkara yang timbul dalam masyarakat. Seperti masalah ekonomi, politik, agama, suku, golongan, harga diri, dan sebagainya yang kemudian dapat menimbulkan konflik horizontal.

Dalam masayarakat Desa,penyelesaian perkara biasanya dilakukan di hadapan Kepala Desa atau Kepala Rakyat yang sering disebut hakim perdamaian desa. Kepala Desa sebagai hakim perdamaian, merupakan tugas dari prajuru desa pakraman dalam menyelesaikan dan mendamaikan perkara-perkara yang terjadi di masyarakat melalui musyawarah dengan perangkat desa dan memberikan saransaran sebagai norma hukum yang berlaku dalam masyarakat desanya demi tercapainya kewibawaan, ketertiban dan keamanan desa, sehingga tidak setiap masalah selalu di limpahkan ke pengadilan Negara karena adanya suatu perkara cukup hanya diselesaikan pada hakim perdamaian desa. Menurut Soepomo ${ }^{21}$ : Suatu pekerjaan lain dari kepala rakyat yang sangat penting pula, ialah pekerjaan dilapangan "represieve rechtsorg" atau pekerjaan sebagai hakim perdamaian desa (dordsjustitie). Apabila ada perselisihan antara teman-teman sedesa, dan ada perbuatan-perbuatan yang bertentangan dengan hukum adat, maka kepala rakyat bertindak untuk memulihkan perdamaian adat, untuk memulihkan keseimbangan di dalam suasana desa, untuk memulihkan hukum ("rechtsherstel") ${ }^{22}$.

Pada hakikatnya, dibeberapa wilayah di Indonesia, seperti di Bali, Aceh, Madura, dan lain sebagainya, nyatanya ada pranata sosial yang menyerupai peradilan masih tetap berjalan selama ini, yang dengan lahirnya Undang-Undang Desa dapat dilembagakan sebagai pengadilan adat yang menjadi bagian dari kelembagaan tradisional desa adat yang dalam definisi hukum disebut dengan "susunan asli" masyarakat hukum adat. Kelembagaan pengadilan adat merupakan pengadilan yang hidup dalam praktek sehari-hari di desa adat (masyarakat hukum adat). Hal ini sesuai dengan Pasal 103 huruf a Undang-Undang Nomor 6 Tahun 2014 tentang Desayang menyebutkan bahwa pengaturan dan pelaksanaan pemerintahan oleh desa adat berdasarkan susunan asli.Susunan asli adalah sistem organisasi kehidupan desa adat yang dikenal di wilayah-wilayah masing-masing ${ }^{23}$.]Dengan merujuk rumusan Pasal 103 huruf a dan dikaitkan dengan Pasal 103 huruf d dan e Undang-Undang Nomor 6 Tahun 2014 tentang Desa, maka kelembagaan pengadilan desa adat adalah pengadilan adat yang dikenal oleh masyarakat hukum adat, baik yang berfungsi memutus, maupun yang berfungsi mendamaikan sengketa adat berdasarkan hukum adat. Artinya, pengadilan-pengadilan yang dikenal oleh masyarakat hukum adat

\footnotetext{
${ }^{21}$ Soepomo, II Bab-Bab Tentang Hukum Adat, Cetakan ke 7, (Jakarta: Pradnya Paramita, 1982), hlm. 69. Lihat juga dalam Dewa Nyoman Anom Rai Putra dan I Nyoman Wita, Kedudukan Dan Tugas Kepala Desa Sebagai Hakim Perdamaian Desa Di Desa Pakraman Taman-Tanda Kecamatan Baturiti Kabupaten Tabanan, Makalah, Hukum Dan Masyarakat, Fakultas Hukum Universitas Udayana, hlm. 1.

22 Ibid.

${ }^{23}$ Penjelasan Pasal 103 huruf a Undang-Undang Nomor 6 Tahun 2014 tentang Desa.
} 
itulah yang kemudian diakui menjadi pengadilan desa adat dalam rumusan UndangUndang Nomor 6 Tahun 2014 tentang Desa ${ }^{24}$.

\section{b. Melacak Peradilan Adat dalam Undang-Undang Otonomi Khusus Bagi Provinsi Papua.}

Provinsi Papua adalah Provinsi yang diberi Otonomikhusus, dan merupakan bagian dari wilayah Negara Kesatuan Republik Indonesia, yangmemiliki keragaman suku dan lebih dari 250 (dua ratus lima puluh) suku dan bahasadaerah serta dihuni juga oleh suku-suku lain di Indonesia. Dari 250 suku yangada di Papua masingmasing memiliki hukum adat tersendiri yang masihbertahan hingga kini $^{25}$.Dalam masyarakat adat, hukum adat dinilai lebihmenguntungkan pihak korban dari pada hukum positif.Norma hukum ditujukan terutama kepada pelaku yang nyata-nyata telah melanggar aturan dan mengganggu tata tertib masyarakat.Dalam hal terjadi pelanggaran hukum atau sengketa, pelaksanaan atau penegakan hukum itu diserahkan kepada kekuasaan kehakiman. Undang-Undang Dasar Tahun 1945 Pasal 24 ayat (2) menegaskan kekuasaan kehakiman dilakukan oleh Mahkamah Agung dan badan peradilan yang berada di bawahnya dalam lingkungan peradilan umum, lingkungan peradilan agama, lingkungan peradilan militer dan lingkungan peradilan tata usaha negara ${ }^{26}$, selain dari keempat peradilan tersebut khusus di Provinsi Papua terdapat lembaga peradilan adat sebagaimana yang diatur dalam Undang-Undang Nomor 21 Tahun 2001 tentang Otonomi Khusus Provinsi Papua .Dalam Pasal 50 ayat (2) dan Pasal 51 menyebutkan bahwa:

"disamping kekuasaan kehakiman sebagaimana dimaksud pada ayat (1), diakui adanya peradilan adat didalam masyarakat hukum adat tertentu. Peradilan adat adalah peradilan perdamaian di lingkungan masyarakat hukum adat, yang mempunyai kewenangan memeriksa dan mengadili sengketa perdata adat dan perkara pidana di antara para warga masyarakat adat yang bersangkutan".

Ketentuan dalam undang-undang Otonomi Khusus Provinsi Papua tersebut menunjukkan fakta dan bukti nyata bahwa peradilan adat di Papua hingga sekarang masih ada dan masih hidup dalam kesatuan-kesatuan masyarakat hukum adat di Papua. Pengakuan terhadap hukum yang hidup (living law) khususnya peradilan adat, sebagaimana ditegaskan Pasal 50 Undang-undang Otonomi Khusus Bagi Provinsi Papua, bahwa disamping badan peradilan umum, pemerintah mengakui adanya peradilan adat di dalam masyarakat hukum adat tertentu.

\section{c. Melacak Peradilan Adat dalam Undang-Undang Pemerintahan Aceh}

${ }^{24}$ Nurul Firmansyah, Menakar Peradilan Desa Adat Dalam UU Desa, dalam Sovia Hasanah, , dalam Rubrik Tanya jawab, hukumonline.com, diakses pada rabu tanggal 28 November 2018.

25 https//id.m.wikipedia.org. Daftar Suku Bangsa di Papua, diakses pada tanggal 28 November 2018.

${ }^{26}$ Pasal 24 Undang-Undang dasar Negara Republik zindonesia 1945 hasil amandemin . 
Aceh merupakan provinsi yang diberikan otononomi khusus, yang pernah terjadi konflik bersenjata, antara Pemerintah Republik Indonesia dan Gerakan Aceh Merdeka (GAM), yang kemudian berakhir damai dengan ditanda-tanganinya Memorandum of Understanding (MoU) di Helsinki Finlandia pada tahun 2005.

Bagi Aceh, Memorandum of Understanding (MoU) tersebut sangat berarti, karena menjadi titik awal bagi mewujudkan periodesasi baru dalam perkembangan Peradilan Adat di $\mathrm{Aceh}^{27}$. Salah satu yang termuat dalam Memorandum of Understanding (MoU) tersebut, adalah terbentuknya Undang-Undang Khusus bagi Aceh yaitu Undang-Undang Nomor 11 tahun 2006 tentang Pemerintahan Aceh. Yang kemudian muncul qanun terkait dengan peradilan adat di Aceh, yaitu : Qanun Aceh Nomor 10 tahun 2008 Tentang Lembaga Adat, yang disahkan 30 Disember $2008^{28}$.

Dengan adanya undang-undang ataupun qanun-qanun di atas maka keberadaan peradilan adat di Aceh telah mulai kembali mendapat tempat dalam sistem perundangan.Meskipun secara substansi, tekait jelas/tegas tidaknya bunyi peraturan tersebut dalam memberikan kepastian hukum bagi keberadaan peradilan adat di Aceh masih terus dapat didiskusikan. Terutama menyangkut dengan kewenangan, tata cara penyelesaian, jenis perkara, sanksi yang diberikan hingga kepada kekuatan hukum setiap keputusan peradilan adat yang diputuskan oleh hakim adat $^{29}$.

Implikasi dari penetapan Undang-Undang Nomor 11 tahun 2006 tentang Pemerintahan Acehdan Qanun tentang Lembaga Adat telah menimbulkan konsekuensi logis pada pemerintah kabupaten di seluruh Aceh untuk menghidupkan kembali lembaga adat yang pernah hidup di wilayahnya masing-masing. Setiap kabupaten diwajibkan untuk menyusun qanun mukim sendiri sebagai wujud dari pemerintahan Adat di daerahnya.Bahkan diharapkan lembaga mukim bisa masuk dan menjadi bagian dari birokrasi pemerintahan Aceh yang membawahi beberapa gampong.Aceh misalnya, terutama setelah diundangkan Undang-Undang Nomor 11 tahun 2006 tentang Pemerintahan Aceh, peluang penerapan peradilan adat tergambar dalam Pasal 98 (2) yang berbunyi, "Penyelesaian masalah sosial kemasyarakatan secara adat ditempuh melalui lembaga adat".

\section{B. Relevansi Eksistensi Peradilan Adat di Indonesia dengan Pembangunan Hukum Nasional.}

Hukum Adat sebagai hukum masyarakat Indonesia semakinmendapat perhatian, terutama dalam rangka pembangunan Hukum Nasional, karena itu dalam pembangunan yang sedang dilaksanakan sekarang ini pembangunan bidang Hukum Adat tidak ketinggalan juga. Hal ini bisa dilihat bahwa dalam perkembangan hokum secara universal, Hukum Adat selalu mendapat perhatian yang sangat penting, yang merupakan salah satu sumber hukum dalam pembentukan Hukum Nasional.Keberadaan hukum adat di samping hukum negara diakui oleh Konstitusi Negara Republik Indonesia sebagaimana

\footnotetext{
${ }^{27}$ Teuku Muttaqin Mansur dan Faridah Jalil , Aspek Hukum Peradilan Adat ..., hlm. 78.

${ }^{28}$ Ibid.

${ }^{29}$ Ibid.
} 
ditentukan dalam Pasal 18 B ayat (2) UUD 1945 yang menentukan: "Negara mengakui dan menghormati kesatuan-kesatuan masyarakat hukum adat beserta hak-hak tradisionilnya sepanjang masih hidup dan sesuai dengan perkembangan masyarakat dan prinsip Negara Kesatuan Republik Indonesia yang diatur dalam undang-undang." Demikian pula Pasal 28 I ayat (3) menentukan : "Identitas budaya dan hak masyarakat tradisionil dihormati selaras dengan perkembangan jaman dan peradaban”. Sesuai dengan ketentuan dalam pasal-pasal Undang-Undang Dasar Negara Republik Indonesia tersebut, maka dapat dikatakan bahwa hukum adat diakui eksistensinya atau keberadaannya sepanjang hukum adat tersebut masih hidup dan sesuai dengan perkembangan masyarakat serta prinsip Negara Kesatuan Republik Indonesia.

Dalam Undang-Undang Nomor 17 Tahun 2007 tentang Rencana Pembangunan Jangka panjang Nasional Tahun 2005-2025, hukum adat sebagai suatu kearifan lokal dalam pengembangan hukum nasional diakui dan dihormati. Dalam rangka menata hukum nasional, maka hukum adat mendapat tempat sebagai bahan penyusunan dan pembuatan peraturan perundang-undangan. Dalam Rencana Pembangunan Jangka Menengah 2004 - 2009, kebijakan dan pembenahan sistem dan politik hukum diarahkan melalui untuk memperbaiki substansi hukum, struktur hukum dan kultur hukum, melalui upaya ${ }^{30}$.

1. Menata kembali substansi hukum melalui peninjauan dan penataan kembali peraturan perundang-undangan untuk mewujudkan tertib perundang-undangan, dengan memperhatikan asas umum dan hierarki perundang-undangan dan menghormati serta memperkuat kearifan lokal dan hukum adat untuk memperkaya sistim hukum dan peraturan melalui pemberdayaan jurisprudensi sebagai bagian dari upaya pembaruan materi hukum nasional. Melakukan pembenahan struktur hukum melalui penataan kelembagaan dengan meningkatkan profesionalisme hakim dan staf pengadilan serta kualitas sistim

2. Menata kembali substansi hukum melalui peninjauan dan penataan kembali peraturan perundang-undangan untuk mewujudkan tertib perundang-undangan, dengan memperhatikan asas umum dan hierarki perundang-undangan dan menghormati serta memperkuat kearifan lokal dan hukum adat untuk memperkaya sistim hukum dan peraturan melalui pemberdayaan jurisprudensi sebagai bagian dari upaya pembaruan materi hukum nasional.

3. Melakukan pembenahan struktur hukum melalui penataan kelembagaan denganmeningkatkan profesionalisme hakim dan staf pengadilan serta kualitas sistimperadilan yang terbuka dan transparan, menyederhanakan sistim peradilan, meningkatkan transparansi agar peradilan dapat diakses oleh masyarakat dan memastikan bahwa hukum diterapkan dengan adil dan memihak pada kebenaran, memperkuat kearifan lokal dan hukum adat untuk memperkaya sistim hukum dan peraturan melalui pemberdayaan jurisprudensi sebagai bagian dari upaya pembaruan materi hukum nasional; meningkatkan budaya hukum antara lain melalui

${ }^{30}$ Rencana Pembangunan Jangka Panjang Menengah Nasional Tahun 2004 - 2009, Bagian III-9, hlm. 5. 
pendidikan dan sosialisasi berbagai peraturan perundang-undangan serta perilaku keteladanan dari kepala negara dan jajarannya dalam mematuhi dan menaati hukum serta penegakan supremasi hukum

Memaknai relevansi eksistensi peradilan adat dengan Rencana Pembangunan Jangka Panjang Nasional Tahun 2005-2025,merupakan hubungan dan keterkaitan antara pembaharuan hukum sebagai sub sistem dalam sistem pembanguan nasional secara menyeluruh dan mendasar. Dihidupkannya kembali peradilan adat dalam sistem peradilan di Indonesia, harus didasarkan atas penghormatan dan perlindungan masayarakt adat, dengan mempertegas secara yuridis normatif, terutama yang menyangkut rumusan dalam peraturan perundang-undangaan, dan sejalan dengan prinsip-prinsipRencana Pembangunan Jangka panjang Nasional Tahun 2005-2025,yang dalam praktek ketatanegaraan dikristalisasi dalam pokok-pokok pembangunan hukum yang tertuangdalam visi dan arah Rencana Pembangunan Jangka Panjang Nasional Tahun 2005-2025, yaitu :

Salah satu tugas yang sampai dengan saat ini belum dituntaskan adalah membentuk Sistem Hukum Nasional Indonesia yang mencerminkan citacita, jiwa, semangat serta nilai-nilai sosial yang hidup di Indonesia.Upaya yang dilakukan antara lain (1) pembaruan peraturan perundang-undangan; (2) pemberdayaan institusi/lembaga hukum yang ada; (3) peningkatan integritas dan moral aparat penegak hukum dan aparatur hukum lainnya; disertai dengan (4) peningkatan sarana dan prasarana hukum yang memadai.Pembaruan peraturan perundang-undangan terus-menerus dilakukan baik dengan mengganti peraturan perundangundangan kolonial maupun berbagai peraturan perundangundangan nasional yang tidak sesuai dengan nilai-nilai sosial dan kebutuhan Bangsa Indonesia. Pemberdayaan institusi hukum dilakukan antara lain dengan peningkatan profesionalisme aparat penegak hukum dan aparatur hukum, serta mendorong agar dalam melaksanakan tugas dan fungsinya, institusi hukum dapat benarbenar independen. Peningkatan integritas dan moral aparat penegak hukum dan aparatur hukum terus dilakukan secara komprehensif tidak saja dengan melakukan penyempurnaan peraturan perundang-undangan; peningkatan kesejahteraan; profesionalisme aparat penegak hukum tetapi juga dengan meningkatkan pengawasan masyarakat terhadap kinerja aparat penegak hukum dalam pelaksanaan tugas dan fungsinya.Peningkatan sarana dan prasarana hukum mempunyai peran yang sangat signifikan untuk menentukan berhasil tidaknya ketiga upaya tersebut. ${ }^{31}$

Dengan demikian kedepan agar eksistensi peradilan adat dalam prakteknya, tidak kerap dibenturkan dengan hukum formal, maka dalam pembenahan hukum nasional secara menyelurh, harus dilihat adanya relevansi sistem peradilan adat dengan peradilan negara, dimana titik temunya, terhadap perkara-perkara yang sederhana, yang itu bisa diselesaikkan secara adat, tidak serta merta dibawa ke ranah Pengadilan Negara, karena sejak zaman pra kemerdekaan, praktek peradilan adat juga diakui, meskipun secara formal lembaga adat ini tidak maksimal, namun dalam kenyataannya dilapangan,

${ }^{31}$ Visi dan Arah Pembangunan Jangka Panjang (PJP) Tahun 2005 - 2025, Kantor Menteri Negara Perencanaan Pembangunan Nasional/ Badan Perencanaan Pembangunan Nasional, hlm. 4. 
mekanisme ini menjadi alternatif lain yang kerap ditempuh para pencari keadilan terutama dalama masyarakat yang masih berbasis kepada pola kehidupan tradisional dengan norma-norma yang menjadi tatanannya.Rasa keadilan yang tidak terpenuhi oleh sistem hukum formal, kadang justru dapat dipenuhi oleh mekanisme peradilan adat yang dalam kerangka sistem hukum yang berlaku adalah peradilan informal.

\section{Penutup}

\section{A. Kesmpulan}

Secara yuridis eksistensi peradilan adat bisa ditemui dalam beberapa peraturan perundang-undangan, yang pada pokoknya peradilan adat adalah peradilan perdamaian di lingkungan masyarakat hukum adat, yang mempunyai kewenangan memeriksa dan mengadili sengketa sengketa adat di antara para warga masyarakat hukum adat yang bersangkutan. Untuk melacak berlakunya kembali peradilan adat bisa dilihat dalam Undang-Undang Darasar Negara Republik Indonesia Tahun 1945 terutama dalam Pasal Pasal 18B ayat (2) dan pasal 24 ayat (3); Undang-Undang Nomor 6 Tahun 2014 tentang Desa, Pasal 103;Undang-Undang Nomor 21 Tahun 2001 tentang Otonomi Khusus Provinsi Papua dalam Pasal 50 ayat (2) dan Pasal 51;Undang Nomor 11 tahun 2006 tentang Pemerintahan Aceh. Yang kemudian muncul Qanun terkait dengan peradilan adat di Aceh, yaitu : Qanun Aceh Nomor 10 tahun 2008 Tentang Lembaga Adat, yang disahkan 30 Disember 2008.

Relevansi eksistensi Peradilan Adat dengan Rencana Pembangunan Jangka Panjang Nasional Tahun 2005-2025,merupakan hubungan dan keterkaitan antara pembaharuan dan pembangunan hukum yang mencerminkan cita-cita, jiwa, semangat serta nilai-nilai sosial yang hidup di Indonesia, dimana pemabngunan hukum yang demikian itu sebagai sub sistem dalam sistem pembanguan nasional secara menyeluruh. Dihidupkannya kembali Peradilan Adat dalam sistem peradilan di Indonesia,maka hukum adat dapat dilaksanakan sesuai fungsinya, dengan mengedepankanpenghormatan dan perlindungan masayarakt adat, dengan mempertegas secara yuridis normatif, terutama yang menyangkut rumusan dalam peraturan perundang-undangaan, yang sejalan dengan prinsip-prinsipRencana Pembangunan Jangka panjang Nasional Tahun 2005-2025.

\section{B. Saran}

Untuk menjamin Peradilan Adat berjalan sesuai dengan fungsinya, maka eksistensi Peradilan Adat dalam praktek agar tidak kerap berbenturan dengan hukum formal, maka dalam pembenahan hukum nasional secara menyelurh, harus dilihat adanya relevansi sistem Peradilan Adat dengan Peradilan Negara, dimana titik temunya, terletak dalam perkara-perkara yang sederhana, yang itu bisa diselesaikkan secara adat, tidak serta merta dibawa ke ranah Pengadilan Negara, sehingga perlu di bentuk Rancangan UndangUndang Peradilan Adat yang mempertegas eksistensi peradilan adat, dalam sistem peradilan di Indonesia. 


\section{Daftar Pustaka}

Abdul Jamali, Pengantar Hukum Indonesia, CV. Raja Wali, Jakarta.

Ketut Sudantra, Pengakuan Peradilan Adat dalam Politik Hukum Kekuasaan Kehakiman, Bali, Udayana University Press, 2004.

Bushar Muhammad, Pokok-Pokok Hukum Adat, PT. Pradnya Paramita, Jakarta, 1983.

Sudikno Mertokusumo, Mengenal Hukum, Yogyakarta, Liberti, 1999

Ewa Wojkoswka, "How Informal Justice System Can Contribute", Paper, United Nations Development Program Oslo Governance Centre, Oslo, Desember 2006.

Subekti, dan R.Tjitrosoedibio, Kamus Hukum, Jakarta, PT Pradnya Paramita, 2003.

Soepomo, R., Sejarah Politik Hukum Adat, 1, Pradnya Paramita, Jakarta, 1982.

Dewa Nyoman Anom Rai Putra dan I Nyoman Wita, Kedudukan Dan Tugas Kepala Desa Sebagai Hakim Perdamaian Desa Di Desa Pakraman Taman-Tanda Kecamatan Baturiti Kabupaten Tabanan, Makalah, Hukum Dan Masyarakat, Fakultas Hukum Universitas Udayana,

Teuku Muttaqin Mansur dan Faridah Jalil, Aspek Hukum Peradilan Adat Di Indonesia Periode 1602 - 2009, Kanun Jurnal Ilmu Hukum No. 59, Th. XV, April, 2013.

Rencana Pembangunan Jangka Panjang Menengah Nasional Tahun 2004 - 2009, Bagian III-9,

Visi dan Arah Pembangunan Jangka Panjang (PJP) Tahun 2005 - 2025, Kantor Menteri Negara Perencanaan Pembangunan Nasional/ Badan Perencanaan Pembangunan Nasional.

Undang-Undang dasar Negara Republik Indonesia 1945.

Undang-Undang Nomor 48 Tahun 2009 tentang Kekuasaan Kehakiman (Lembaran Negara Republik Indonesia Nomor 157 Tahun 2009, Tambahan Lembaran Negara Republik Indonesia Nomor 5076).

Undang-Undang Nomor 6 Tahun 2014 tentang Desa. Lembaran Negara Republik Indonesia, Tahun 2014 No. 7

Undang-Undang Nomor 21 Tahun 2001 tentang Otonomi Khusus Provinsi Papua Undang Nomor 11 tahun 2006 tentang Pemerintahan Aceh.

Qanun Aceh Nomor 10 tahun 2008 Tentang Lembaga Adat

Tim Penyusun Pusat Pengembangan Bahasa, Kamus Besar Bahasa Indonesia, Jakarta : Balai Pustaka, 1990.

Htps//id.m.wikipedia.org. Daftar Suku Bangsa di Papua, diakses pada tanggal 28 November 2018. 